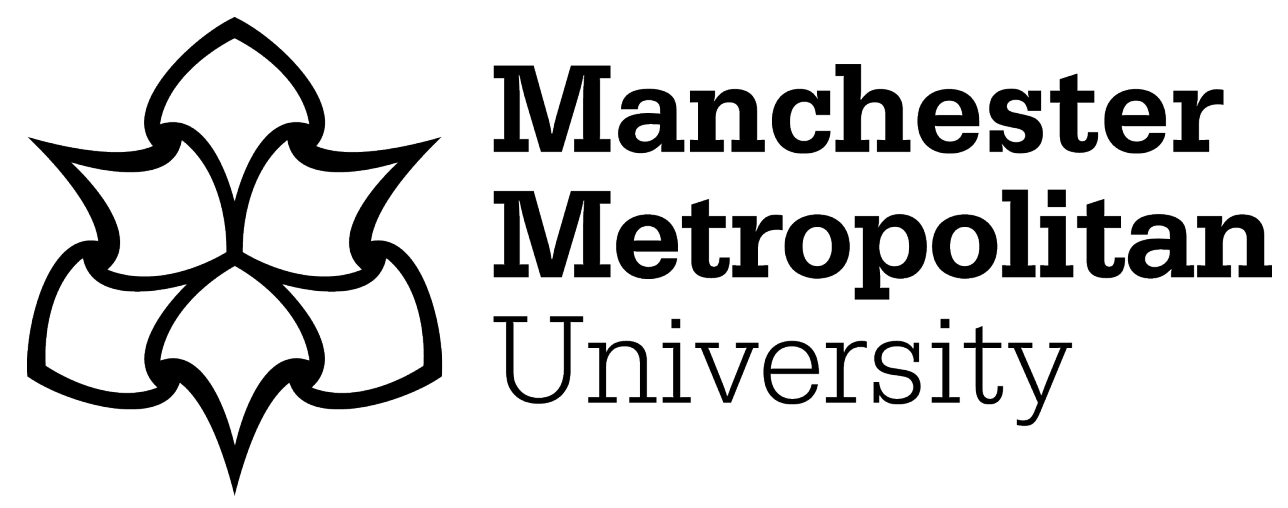

Klesse, Christian (2018) Bisexuality, Slippery Slopes, and Multipartner Marriage. Journal of Bisexuality, 18 (1). pp. 35-53. ISSN 1529-9716

Downloaded from: https://e-space.mmu.ac.uk/619304/

Version: Accepted Version

Publisher: Taylor \& Francis (Routledge)

DOI: https://doi.org/10.1080/15299716.2017.1373264

Please cite the published version 


\section{Bisexuality, Slippery Slopes, and Multipartner Marriage}

\section{Christian Klesse}

\section{Introduction}

This paper explores the position of polyamory and bisexuality in slippery slope arguments directed against the campaign for same-sex marriage rights in the United States. A slippery slope designates an 'idiom that, by definition, means "an idea or course of action which will lead to something unacceptable, wrong, or disastrous"', linking situations in a scenario according to which allowing one will inevitably lead to an objectionable other (The English Oxford Living Dictionaries, 2017; see Rambukkana, 2015). Slippery slope arguments are frequently deployed in the field of legal debate. In the rhetoric of right-wing opponents legalising same-sex marriage is seen as the first step on a long spiral downwards toward moral decay, which will successively normalise a whole range of problematic and 'unwanted' practices. Polygamy, and in its close proximity polyamory, are usually the first items on a list that may further include adultery, adult incest, bestiality, pedophilia, etc. (Emens, 2004). The paper highlights the mobilisation of racist and nationalist tropes at the heart of anti-polygamy sentiments and explores the role of bisexuality in representations of polyamory. It thereby aims to provide a corrective to the common invisibility of bisexuality in the analysis of marriage equality debates (see Galupo, 2009). The critical analysis of a selection of essays published by the conservative US journalist Stanley Kurtz highlights the conflation of polyamory with bisexuality in some slippery slope scenarios. Engaging with Kurtz's work is important because it has been popular in policy-making circles and monitors closely developments within cultural theory and political activism in order to counter the legal recognition of relationship diversity.

Slippery slope arguments have been a constant feature of the debates about samesex marriage rights in the USA and other countries (Cardoso, 2014; Pallotta-Chiarolli, 2010; Pérez Navarro, 2017; Rambukkana, 2015; Sheff, 2011). Analysing the slippery slope dynamic 
is important for understanding both the conditionality of the persisting hostility against consensual non-monogamies and LGBTQ $^{1}$ intimacies and the shape of social movement politics that aim to challenge it. In particular, the article shows that the 'concept shift' (Jefferson, 2014) at the heart of the sequences that links same-sex marriage with polygamy and polyamory mobilises profoundly racialised representations sustained by the legacies of racism and settler colonialism.

\section{Same-Sex Marriage, Plural Marriage, and the Slippery Slope}

The campaign for same-sex marriage rights has been on the top of the agenda of LGBT lobbying organisations for many years. After decades of strategic litigation in both state and federal courts, activists for marriage equality in the USA were able to celebrate major successes over the last few years. Two United States Supreme Court Decisions finally paved the way to same-sex marriage. United States v. Windsor (2013) declared Section 3 of the Defence of Marriage Act (DOMA) (1996) as unconstitutional under the Due Process Clause and the Fifth Amendment. This Section had specified that the term 'marriage' only applied to monogamous heterosexual legal unions and that the term 'spouse' was limited to a husbands and wives in 'other-sex' couple relationships. In Obergefell v. Hodges (2015), the United States Supreme Court finally held that the 'fundamental right to marry' could not be withheld from same-sex couples in the light of the Due Process and the Equal Protection Clause of the Fourteenth Amendment to the United States Constitution (Denniston, 2015). Obergefell over-ruled all remaining state laws that either ban same-sex marriage or refuse to recognise marriages that were conducted in a different state. The positive results of litigation for civil marriage rights for same-sex couples has brought the question of marriage 
rights to the fore in the debates within polyamory activism. Aviram and Leachman (2015) notice a stronger engagement with questions of legal recognition of multi-partner families on poly Conferences and Conventions in the United States (ibid., p.306). This is a significant change since large parts of the polyamory movement have been wary of marriage, seeing it as an assimilationist practice prone to normalising poly intimacies by imposing an inflexible template, forcing poly activists to present themselves in a respectable and des-sexualised way, or legitimising the state regulation of people's intimate and sexual behaviours (Aviram, 2010). This normative aspect of same-sex marriage is well expressed in the following statement of Jodi O'Brien (2007, p. 144): '[S]ame gender marriage is likely to perpetuate a status quo that favours one particular family form and concurrent set of cultural expectations and practices'. Same-sex marriage narrows the scope of legal recognition by deflecting from more unconventional relations and zooming in on the more familiar settings of couple based units (Barker, 2012, p. 182).

Most poly activists have refrained from touching upon the question of legal recognition of multipartner relationships because they feared that such a step would undermine the chances of same-sex marriage activists to advance their agenda (Aviram \& Leachman, 2015). This has been the case primarily because opponents of marriage equality successfully mobilised cultural anxieties that granting civil marriage rights to same-sex couples would debase the institution of marriage, empty it of its values and civilising function by triggering a process that will ultimately open it up to other 'unwanted' groups, such as polygamists, polyamorists, pedophiles, etc. This scenario rests on the assumption that same-sex marriage will shatter the cultural consensus that only a monogamous 
heterosexual union presents a proper family that provides a healthy and natural environment for raising children (cf. Sheff, 2011; Whitehead, 2012).

Senator Rick Santorum declared in an interview with AP (Associated Press) before the landmark decision in Lawrence v. Texas (2003) which struck down Texas sodomy legislation that 'if the Supreme Court says that you have the right to consensual sex within your home, then you have the right to bigamy, you have the right to polygamy, you have the right to incest, you have the right to adultery. You have the right to anything.' (USA Today 2003; see also Loughlin, 2003).

Dissenting judge Justice Scalia, too, evoked a slippery slope scenario, when he challenged inevitable negative consequences of the libertarian impulse enshrined in Lawrence v. Texas.

'State laws against bigamy, same-sex marriage, adult incest, prostitution, masturbation, adultery, fornication, bestiality, and obscenity are likewise sustainable only in light of Bowers ${ }^{2}$ validation of laws based on moral choices. Every single one of these laws is called into question by today's decision' (Lawrence v. Texas, 2003, p. 590).

One (unwelcome) legal change will thus lead to another, with moral decline being the inevitable consequence. The same rationality has structured the slippery-slope-type of arguments against same-sex marriage. The following argument by Stanley Kurtz is a good example:

'Once we say that gay couples have the right to have their commitments recognized by the state, it becomes next to impossible to deny that same right to polygamists, polyamorists, or even cohabiting relatives and friends. And once, every one's 
relationship is recognized, marriage is gone, and only a system of flexible relationship contracts is left' (Kurtz, 2003).

Monogamy and the dyadic principle are described as the unique qualities of marriage that define its spiritual essence and secure its unity and status as a normative cultural institution. Kurtz aligns himself with a long tradition within US marriage law that sees marriage as a natural and quasi-sanctified, if not God-given, institution whose meanings go far beyond the logic of a civil contract (Ertman, 2010). Contract logic will trigger the slippery slope and polygamy and polyamory are named as the first items on the list of unwelcome consequences. Before I will explore the discursive features of these links, it is worthwhile to look a bit closer at the linguistic qualities of slippery slope arguments.

According to Stenvoll Doug (2008), slippery slope arguments imply movement and inevitability within a process-logic. This reasoning tends to reframe politics as a quasiphysical process by connecting concepts like material objects in a way that implies unilinear notions of impact and causality. This is reductionist and decomplexifies politics. Moreover, the directionality of slippery slope metaphors is almost always downward, drawing on a symbolism that equates upward with good and downward with bad. At the heart of slippery slope arguments operates a distinctive kind of metaphorical reasoning (either as a cognitive process or an ideological attempt at framing) that associates different categories with each other, stressing their similarity, proximity or - in extreme cases - identity. In the case of the debates on marriage equality, same-sex marriage has been persistently linked with polygamy and polyamory without any regards for the differences between these concepts and practices (Denike, 2010). 


\section{'Un-American Intimacies': Polygamy, Criminal Law, and the Nation State}

There is a long history of anti-polygamy sentiment in the United States and polygamy has been criminalised since the $19^{\text {th }}$ century by the means of anti-bigamy laws relating to federal court and Supreme Court rulings (Burgett, 2005; Myers, 2009). Monogamy has been endorsed a natural or divine (Christian) institution and a symbol of civilisation in many European countries and (European) colonial settler societies across the globe (Willey, 2006), but the anti-polygamy campaign in the United States has been propelled by a peculiar mixture of cultural tensions and political collisions closely bound up with its national history. According to Martha Ertman (2010), the contemporary ban of polygamy in the United Sates stemmed from $19^{\text {th }}$ century attempts to contain Mormonism as a cultural and political force and to stop the Mormon Church from establishing a separatist theocracy in Utah which led to accusation of both political and race treason (see also Cott, 2000; Myers, 2009; Strassberg, 1997). Mormons were cast as backward and primitive for adopting a form of marriage that was considered to be natural for Asian, African or native American groups, but not for white citizens of the United States. The condemnation of the allegedly 'primitive' Mormon marriage model that was conflated with promiscuity reveals the profoundly racialised character of marriage as an institution. The racial dimension of the project of marriage in US history is underscored by the destruction of African family ties through the period of slavery (Davis, 1982), the pathologisation of Black families in post-slavery US family policy (Cooper, 2001), the history of anti-miscengenation laws (Battalora, 2009), and the prevalence of racialised inequalities within the sphere of intimacy through the persistence of racist representation of Black genders after Loving v. Virginia (Collins, 2004). The discussion about polygamy and plural marriage in the USA is a key process indicating 
the 'centrality of racial politics to marriage regimes' (Stacey and Meadow, 2009, p. 167) and the iconic position of monogamy in discourses of white supremacy (Schippers, 2016).

It was due to the charges of non-monogamy and promiscuity that Mormons were cast as a distinct degenerate race, i.e. as non-White and/or as traitors of the white race. The alleged physical degeneration of Mormons was then linked again with a critique of the group's alleged submission to despotism, seen as a 'primitive form of government [that] was common among supposedly backward races' (Ertman, 2010, p. 289, see also Burgett 2005). Popular depictions of Mormons (in newspapers, magazines, and cartoons) represented them as Black or Asian and their offspring as disorderly and multiply racialised. This reveals the centrality of miscegenation fears to the anti-polygamy campaigns after the issuing of the Civil Rights Act of 1866 and the $14^{\text {th }}$ Amendment of the Constitution of 1868.

The disparaging and racist framing of polygamy in Reynolds v. United States (1879) are illustrative of these concerns. The Court suggested that polygamy was offensive to northern and western European national cultures and 'almost exclusively a feature of the life of Asiatic and African people' (Reynolds v. United States, p. 164). Polygamy has thus been defined as 'un-American' in both popular and legal discourse and racism has shaped perceptions of plural marriage since the $19^{\text {th }}$ century (Stacey \& Meadow, 2009).

At the same time, polygamy is seen as a hyper-patriarchal practice in which no women would ever engage in as a result of her free decision. Plural marriage is primarily looked at from the point of view of harm (for both women and children) (Gher, 2008; Rambukkana, 2015). 'Since the $19^{\text {th }}$ century, critics have associated polygamy with male power and sexual promiscuity and portrayed it as antithetical to women's interests', state Stacey and Meadow (2009, p. 183). Many feminist critics of the practice have asserted the 
association of polygamy with constraints on women's autonomy, girls' lack of access to education, child poverty, marriage under the age of consent, sexual abuse, and rape (Chatlani, 2006). Others, however, argue that these problems are not limited to polygamous intimacies, that it is wrong to stigmatise entire communities, and that legal and policy frameworks other than an out-right ban would be in place to address such problems should they occur within the context of polygamous intimacies or elsewhere (Lenon, 2016). Moreover, Ertman (2010) suggests that the gender equality and the well-being of children was never the sole concern of US anti-polygamy law which did not only ban the practice of plural marriage but further stripped polygamists of other rights, including immigration, advocating polygamy or holding a public office (see also Burgett, 2005 and Klein, 2010). For Ertman, 'race is at the center of antipolygamy law, in a way that forces us to rethink the ban itself' (2010, p. 288).

The same applies to anti-polygamy laws in Canada. Anti-polygamy laws in Canada were legitimised by the threat of fundamentalist Mormons emigrating from the United States to Canada in the 1880 s and 1890 s in order to escape state persecution on the other side of the border. However, as Denike (2010) explains, the law was crafted in a way that allowed it to be used against any form of polygamy deemed to be 'un-Christian' in nature and spirit. For instance, Canadian criminal anti-bigamy laws were first used to persecute aboriginal peoples. 'The new criminal law was instrumental in consolidating the religious persuasions and customs of the new nation against the Jewish, Muslim, Asian, Indian, and Aboriginal customs with which polygamy was associated' (pp. 139-140). Anti-bigamy laws were core to the politics of white supremacy that underpinned the erasure of indigenous ways by settler colonialism (Lenon, 2016). The 2011 judgement Reference re: s.293 of the 
Criminal Code of Canada of the British Columbian Supreme Court that upheld the constitutionality of the prohibition of polygamy reproduces many of the tropes that have driven white settler colonial framings of polygamy since the $19^{\text {th }}$ century (Ashley, 2014).

The history of anti-polygamy legislation in North America demonstrates that racism has been deeply intertwined with these laws and that marriage and monogamy are profoundly racialised cultural practices. Whenever morally conservative opponents of same-sex marriage evoke the threat of polygamy, they also mobilise these assumptions and associations. The linkage of Mormon polygamy with African or Asiatic practices that were said to be 'odious among the northern and western nations of Europe' in law (Reynolds $v$. United States 1879, p. 164) and in representations within popular culture (Burgett, 2005 and Ertman, 2010) produced a discourse of this group persisting predominantly of white Christians as 'metaphorically non-white' (see Cott, 2000). However, this process should not let us overlook the fact that most Mormons in the USA are white and that leaders of the fundamentalist movement have been subscribing to a racist vision of white supremacy (see Manson, 2005). However, more recently polygamy has also been a salient topic within the repertoire of Islamophobic discourse that implicitly or explicitly targets other racialised groups, such as people of Asian descent (Puar, 2007; Rambukkana, 2015)

The repetitive positioning of polyamory next to polygamy within downward spiralling slippery slope sequences results in polyamory, too, being associated with these judgments, without the speaker ever having to make the effort of having to argue about similarities and differences in detail. The 'repetition of proximity', Ahmed (2011) argues, can render associations 'essential' in perception. Within this process, an alleged 'essential' affinity between polygamy and polyamory is asserted and polygamy's racialised attributes pass over 
and start to 'stick' (see Ahmed, 2004). The racial imagery bound up with plural marriage is a potent agent that helps to explain some of the anxieties that are mobilised by slippery slope scenarios.

In the following section, I will look at how polygamy and polyamory figure in the slippery slope discourse of the Conservative journalist Stanley Kurtz. Kurtz's work is interesting because it explicitly addresses the role that bisexuality plays in polyamory cultures and because it reflects bisexuality's strategic value for pushing equality-based arguments for plural marriage. In the context of this discussion, it is important to keep in mind that bisexuality, too, has historically been represented as a primitive cultural trait and an atavistic throw-back of the evolutionary process (see Angelides, 2000; Storr, 1999). Even if the traces of these histories are not easily discernible at the surface of contemporary discourses on bisexuality, they form an integral element of the racialised dynamics that have driven the debates on polygamy and same-sex marriage.

\section{Polyamory and Bisexuality in the Cultural Critique of Stanley Kurtz}

Polyamory has been mentioned in slippery slope arguments against same-sex marriage rights in the courts and within the wider media sphere (Antalffy, 2011; Whitehead, 2012). It was deployed by a wide range of public figures, including the former Senator Rick Santorum, the former Supreme Court Justice Antonin Gregory Scalia, the founder of 'Focus on the Family' James Dobson, and the anthropologist and journalist Stanley Kurtz, whose conservative commentaries have appeared in many publications, including The Weekly Standard and The National Review. Kurtz work has been widely disseminated within the networks of conservative and right-wing Christian organisations, such as the Family 
Research Council, Focus on the Family, Concerned Women for America and the Traditional Values Coalition. They were cited in Congress debates and referred to by federal government staff (Ashbee, 2007). The influence of Kurtz's work can also be inferred from the fact that it is discussed in most publications critical of the slippery slope reasoning (Antalffy, 2011; Pallotta-Chiarolli, 2010; Sheff, 2011). While Kurtz's work has been frequently commented upon, his treatment of bisexuality has not yet been tackled in detail. In the following, I refer to a small number of selected articles that address same-sex marriage through the prism of slippery slope scenarios that also involve references to nonmonogamy, polygamy, polyamory, homosexuality or bisexuality. In ‘Beyond Gay Marriage: The Road to Polyamory' Kurtz (2003) presents an anti-promiscuity argument that is based on ideas that are deeply engrained in homophobic equations of gay men with excessive sexualisation (cf. Warner, 1999; Klesse, 2007).

"The trouble is, gay marriage itself threatens the ethos of monogamy. The "conservative" case for gay marriage holds that state-sanctioned marriage will reduce gay male promiscuity. But what if the effect works in reverse? What if, instead of marriage reducing gay promiscuity, sexually open gay couples help redefine marriage as a non-monogamous institution? There is evidence that this is exactly what will happen' (Kurtz, 2003).

Same-sex marriage (cast as 'gay marriage' in Kurtz's terminology) ${ }^{3}$ will break the connection of marriage with monogamy and thus lead to polygamy and polyamory. This is just a question of time: 'The gay marriage movement took more than a decade to catch fire. A movement for state-sanctioned polygamy-polyamory could take as long', suggests Kurtz (2003). According to Kurtz, one of the last features of 'proper' marriage that has survived 
the tides of time is monogamy. Breaking this link will undermine the vital function of marriage to create stable families. While Kurtz warns of both the legalisation of polygamous and polyamorous marriage, evoking the possibility for multiple partner choice outside of a monosexual framework (i.e. gender-plural polyamory) seems to be an even more troubling vision of plural marriage than heteronormative polygyny.

Kurtz discusses polygamy and polyamory in a parallel fashion: Both are associated with promiscuity, even if in slightly different ways. In the case of 'non-Western' polygamy, the problem is defined as one of adulterous male promiscuity. Kurtz cites a Nigerian survey of sex out-side of marriage in order to underscore his point. 'Even though polygamous marriage is less about sex than security, societies that permit polygamy tend to reject the idea of marital fidelity for everyone, polygamists included', Kurtz (2003) argues. With regard to Mormon polygamy, Kurtz alleges that although contemporary Mormon ethics condemn non-marital sex and advocate romantic notions of love, polygamous arrangements would be instable and unpractical. Because of this, 'polygamy let loose in modern secular America would destroy our understanding of marital fidelity, while putting nothing viable in its place' (Kurtz, 2003).

Kurtz then goes on to discuss polyamory as a form of 'postmodern polygamy'. Polyamory, is described as a shrouded mode of promiscuity: 'Supposedly, polyamory is not a synonym for promiscuity. In practice, though, there is a continuum between polyamory and "swinging."' (Kurtz, 2003). Whereas polygamy is at least predictable because it is moulded by patriarchal interpretations of heterosexuality, polyamory is shaped by fluidity, excess, and unpredictability. Kurtz evokes bisexuality as a figure of bewilderment and confusion, the major function of which seems to be the undoing of any certainty regarding desire and 
partner choice. 'Unlike classic polygamy, which features one man and several women, polyamory comprises a bewildering variety of sexual combinations. There are triads of one woman and two men; heterosexual group marriages; groups in which some or all members are bisexual; lesbian groups, and so forth', states Kurtz (2003). Kurtz mentions bisexuality once in passing. However, in a later article, Kurtz engages with bisexuality in much more detail, this time treating it as a fully rationalised concept that functions as a hinge between and same-sex marriage and plural marriage in legal strategies of the marriage equality movement.

\section{Routes to Plural Marriage: Bisexuality, Sexual Orientation, and Equal Protection}

In 'Here Come the Brides. Plural Marriage is Waiting in the Wings', Kurtz (2005a) objects to equality arguments based on 'sexual orientation' reasoning. If gay marriage should be legalised, because the right of marriage cannot be denied to a sexual minority, then other organised minorities will be able to do the same. Kurtz's discussion is primarily concerned with 'polyamory', but in many parts his argument rests on theorising the connection between polyamory and bisexuality. 'TWO DEVELOPING LINES of legal argument may someday bring about state recognition for polyamorous marriage: the argument from polyamory, and the argument from bisexuality', Kurtz argues. In his analysis of the legal arguments around polyamory, Kurtz engages with Emens's (2004) suggestion to consider polyamory as a disposition (cf. also Kurtz, 2005b). While Emens assumes that there is a little bit of 'poly' inside all of us, some people are more intensely dispositioned to polyamory than others. 'Whether for biological or cultural reasons, says Emens, some folks simply cannot live happily without multiple simultaneous sexual partners. And for those people, 
Emens argues, our current system of marriage is every bit as unjust as it is for homosexuals' (Kurtz 2005a). Although Emens shies away from stating a (psychobiological) sexual orientation argument, her framing of disposition as a minoritarian position allows for an analogy with homosexuality, i.e. a status widely recognised to be a 'sexual orientation' (Klesse, 2014, 2016).

In his discussion of the legal arguments around bisexuality, Kurtz (2005a) turns to Yoshino's (2000) influential article 'The Epistemic Contract of Bisexual Erasure'. Although Yoshino does not define bisexuality as a sexual orientation, Kurtz highlights tropes which can be developed into this direction. 'Defining bisexuality as a "more than incidental desire" for partners of both sexes, Yoshino examines the best available academic studies on sexual orientation and finds that each of them estimates the number of bisexuals as equivalent to, or greater than, the number of homosexuals' (ibid.). Bisexuals, even if not often recognised as a 'sexual orientation' in their own right, can thus be seen as the largest sexual minority on the LGB spectrum, out-numbering lesbian and gay men (see Eisner 2013).

After Kurtz has documented discourses that establish bisexuality as a sexual orientation, he aims to demonstrate an innate connection between bisexuality and polyamory. Kurtz acknowledges that many bisexuals are monogamous, but then points out research that highlights strong proclivities toward polyamory within bisexual communities (cf. Rust, 1996). Polyamory would therefore be sufficiently engrained in that 'more than incidental desire' of bisexuality to make claims to the rights of multipartner marriage on the grounds of a sexual orientation-based minority status plausible and justifiable. This is why gay marriage will lead to bisexual marriage and group marriage. 'If every sexual orientation 
has a right to construct its own form of marriage, then more changes are surely due. For what gay marriage is to homosexuality, group marriage is to bisexuality' (Kurtz, 2005a).

Kurtz reminds those who do not take this development seriously, e.g. because they believe bisexuality or polyamory to be merely fringe phenomena, that the social movements associated with these identities are on the rise, which will provide advocates with the resources and organisational strongholds necessary for advancing litigations. Kurtz inserts quotes of a contributor to the 2004 Polyamory special issue of the Journal of Bisexuality to highlight the coalitional aspirations and potentials of bi/poly activism, including the statements: 'Poly activism is bi activism.... The bi/poly dynamic has the potential to move both communities towards a point of culture-wide visibility, which is a necessary step on the road to acceptance.' (Mint 2004, 72 and 73, as cited in Kurtz, 2005a). For Kurtz, mobilisations around bisexuality provide key rationales for plural marriage based on equality arguments. It is interesting to note that with the advancement of marriage equality in the United States, several authors have made the proposal to frame bisexuality or polyamory as sexual orientations to advance the right to plural marriage. 'Because bisexuals are attracted to both men and women, expressing their sexual identity fully might require simultaneous relationships', proposes for example Elizabeth Brake (2013). Aviram and Leachman (2015), too, suggest that a legal strategy based on an Equal Protection Clause arguments regarding sexual orientation could provide a successful strategy for opening up civil marriage to plural partnerships. Such sexual orientation-based equality strategies could be founded upon sexual orientation models of either bisexuality or polyamory. The authors indicate a preference for the latter (i.e. the polyamory approach), because it would be more inclusive and does not necessarily depend upon binary constructs of gender or on specific 
gender constellations to effectively show discrimination in the courts (see Klesse 2016, 1362-1363). In 'Here Come the Brides. Plural Marriage is Waiting in the Wings', Kurtz (2005a) presents an entirely secular, social-science-led analysis of the political and legal mobilisation within legal equality movements to bolster a slippery slope argument.

\section{Polygamy, Polyamory, and Processes of Racialisation}

My discussion in the last two sections has shown that Kurtz attributes bisexuality a central role in his slippery slope rejections of same-sex marriage. Multiple conflations of bisexuality with polyamory are at the heart of this analysis. Firstly, Kurtz utilises bisexuality as a figure symbolising the destruction of orderly structures of desire and the principle of dyadic heterosexual monogamy and commitment. Secondly, he describes bisexuals as a core population of polyamorous constituencies and identifies the bisexual movement as the driving force behind poly activism. Thirdly, he suggests that bisexuality can provide the key concept for building a compelling case for plural marriage through litigation. Kurtz's discussion of polygamy, polyamory, and bisexuality also contains references to race. The only backing Kurtz (2003) offers for his claim of the affinity of polygamy with adulterous promiscuity in non-Western countries is a citation of a study of sexual behaviours in Nigeria. This particularises African sexualities as being prone to promiscuity and thereby reproduces long-standing stereotypes (Mercer \& Isaac, 1988). Allusions to romantic love, companionate marriage, and a commitment to parity between different wives in contemporary US Mormonism is read by Kurtz as reflecting an 'effort to create a hybrid traditionalist/modern version of Mormon polygamy' (Kurtz, 2003). However faulty in practice, western versions of polygamy are represented as being relatively advanced on the evolutionary road from 
traditionalism (polygamy) to modernity (romantic love and conjugal gender parity). This conflation of geo-political and temporal themes within the logic of evolutionism is sustained by a racialising rationality (McClintock, 1995). Polygamy is coded as a backward traditional practice (with racialised, non-western origins) that has undergone an uncompleted process of modernisation within successive revisions of white US Mormonism. According to Kurtz (2003), polyamory is just one step further along this line of temporal development: 'AMERICA'S NEW, souped-up version of polygamy is called "polyamory"', a kind of 'postmodern polygamy'.

In the previous section, I have stated that Kurtz claims a continuity between polyamory and swinging, a move with which he aims to prove the allegedly promiscuous nature of polyamory. When Kurtz explicates this view, he returns to the example of an alleged Nigerian polygamous/ adulterous promiscuity, which, according to Kurtz, (2003) could be understood to be a precursor of polyamory:

'And since polyamorous group marriages can be sexually closed or open, it's often tough to draw a line between polyamory and swinging. Here, then, is the modern American version of Nigeria's extramarital polygamous promiscuity. Once the principles of monogamous companionate marriage are breached, even for supposedly stable and committed sexual groups, the slide toward full-fledged promiscuity is difficult to halt.'

Bisexuality, polygamy, and polyamory thus are linked in a chain of signification that operates both explicit and implicit strategies of racialisation. 


\section{The Effects of Sequencing: Polygamy, Polyamory, and Bisexuality as 'Problems' in Marriage Equality Activism}

Although both polygamy and polyamory have a steady appearance in slippery slope arguments, it has been polygamy which has provided the more dominant framework. This is likely to be due to the long history of debates on polygamy in the United States, which by far precedes the cultural emergence of polyamory in the second part of the $20^{\text {th }}$ century. As said, polygamy is usually the first problem mentioned, whenever slippery slope scenarios regarding same-sex marriage are evoked (Denike, 2010, p. 141). Polyamory is often the second item on the list. The sequencing of items within slippery slope arguments does not only establish a connection between the first term and the following ones, but also among the following terms with each other. It is therefore worthwhile to reflect not only on the effects of the discursive framing of the connection between same-sex marriage and polygamy and polyamory respectively, but also on the implications of the pairing of polygamy with polyamory.

So called 'empirical' slippery slope arguments construe temporality and operate on the grounds of a consequentialist rationality (Volokh, 2003). Applied to the same-sex marriage debate, this is reflected in the assumption that the creation of same-sex civil marriage would create a legal precedence that will propel a dynamic that will lead to the realisation of legal frameworks for plural marriage. However, even empirical slippery slope arguments are rarely concerned with simple questions of predictability and likelihood. Rather they negotiate the moral implications of certain decisions. On this level, they also pertain to logical and conceptual matters, such as in so-called 'no-principled distinction' arguments. According to Jefferson (2014, p. 673), slippery slope sequences that are 
constructed around a logic of 'no-principled distinction' attempt 'to show that two cases considered to be morally different are analogous in morally relevant ways. Therefore, the wrongness of $B$ implies the wrongness of $A$ '. The most common form of the 'non-principled distinction' argument is directed 'against the starting point of the slope on the basis that the principles licensing its acceptance would also license the endpoint' (2014, p. 673). Applied to the same-sex marriage debate, this means that same-sex marriage (already opposed on its own) will license other problematic practices, such as polygamy and polyamory. Variants of both empirical and logical argumentative schemes can be identified in the texts by Kurtz (2003, 2005a).

Slippery slope arguments dissolve the distinction between polygamy and polyamory allowing for a 'concept shift' (Jefferson, 2014) and the transference of the racialised connotations onto polyamory (defined as a 'postmodern' form of polygamy in the words of Kurtz (2005a). This has been particularly troubling for activists advocating marriage equality. In North America, LGBT marriage equality activists and their allies have usually rejected any connection between an argument for the right to marriage for same-sex couples and polygamy. Many have asserted a fundamental difference between same-sex marriage and plural marriage, describing polygamy as patriarchal and incomparable with the genderegalitarian promises of same-sex marriage (see Denike, 2010; Fischel, 2016; Redding, 2010). This response can be seen as both an effect and an integral part of 'homonationalism', which is defined by Puar (2007, p. 39) as a 'collusion between homosexuality and American nationalism that is generated by national rhetorics of patriotic inclusion and queer subjects themselves'. Many proponents of same-sex marriage have further distanced themselves from polyamory, too, because coalitions with polyamorists have been seen as damaging to 
the realisation of one's own interests. Maria Pallotta-Chiarolli (2010, pp. 7-8) argues that 'some advocates of non-heterosexual marriages and families endeavour to reassure fundamentalists such as Kurtz that the slippery slope fears will not be realized, as only those relationships that are monogamous same-sex couples are "normal families like straights have"'. Aviram and Leachman (2015) talk about the common embitterment and resentment among poly activists, who feel that they have been let down by LGBT same-sex marriage activists.

Of course, it is necessary to recognise that poly activists, too, have often tried to deny or downplay any overlap regarding the experience or interests with polygamy (Emens, 2004; Strassberg, 2003). Many believe that the conflation of polyamory with conventional religious polygyny explains much of the anti-polyamory sentiments in North American culture (Emens, 2004; Tweedy, 2011). There have been longstanding boundary skirmishes between polyamory and Mormon - but also Muslim - polygyny, which go right at the core of the definition of polyamory. Emens (2004, p. 307) argues: 'The sex-based hierarchy of traditional Mormon polygyny seems incompatible with the typical poly dedication to principles of quality and individual growth, causing some polys and commentators to exclude Mormon polygyny from the umbrella of polyamory'. Few poly advocates take a more inclusive stance in this regard (see, for example West (1996), who was herself raised in a Mormon family).

'Polyamory has been a constant focus of opposition to same-sex marriage, figuring strongly in arguments made both inside and outside the courtroom', state Aviram and Leachman (2015, p. 2640), a fact that has shaped the discursive terrain for any attempts to raise the issue of poly relationship rights. The authors believe that rather than opening 
space for an effective mobilisation around poly relationship rights, the history of LGBT activism around same-sex marriage may have narrowed this spaces at least in so far as the standing of polyamory in the public sphere is concerned. If this assessment is correct, poly activism finds itself in a paradoxical situation. For the first time, at least certain factions of the poly community seem to have developed a taste for probing for legal relationship recognition. In the light of Obergefell $v$. Hodges (2015), questions of plural marriage are very likely to move to the fore even further (deBoer, 2015; Fischel, 2016).

In the face of this situation, it becomes urgent for polyamory activists to clarify their position with regard to the question of marriage and their relationship to other styles of consensual non-monogamy. We have seen that attempts to reject the slippery slope by advocates of marriage equality have often led to homonormative or polynormative responses (cf. Puar, 2007; Wilkinson, 2010). Dealing with slippery slope arguments demands careful reflection, if we wish to avoid the pitfall of disassociation that is implicitly encouraged by the structure of these arguments. I have argued that such reflection needs to include a refutation of the racism that has been bound up with the debates on polygamy in North America (Rambukkana, 2015).

\section{Conclusion}

Decades of legal activism and litigation have paved the way for same-sex marriage in the USA. Mainstream lobbying groups have construed the question of relationship recognition for LGBT intimacies and families as a question of marriage equality. This strategy has always been contested by feminist, queer-inspired or anarchist LGBTQ activists who see marriage as an implicitly heteronormative institution and a status that monopolises privilege 
(Auchmuty, 2004; Polikoff, 2009; Warner, 1999; Whitehead, 2012). In this paper, I have not engaged in close detail with the critique of the politics of marriage (see Klesse, 2016 for a more thorough discussion). Rather, I have been primarily concerned with cultural and legal aspects of the culture wars around marriage equality. In the USA, plural marriage has always been close to the heart at the controversies around same-sex marriage. Conservative opponents of same-sex-marriage have deployed the spectre of the legal right to polygamy as a deterrent in the name of 'traditional family values'. By dismissing association between same-sex marriage and polygamy 'as rhetorical ruses for homophobia', activists fail to explore the complex legacy of popular anxieties regarding marital diversity (Stacey and Meadow, 2009; see also Burgett, 2005).

I have argued that questions of race, racism and colonialism are deeply implicated in these anxieties. Bisexuality is drawn into this process through the equation of bisexuality with polyamory. '[C]ompulsory monogamy insists on dyadic resolutions for all regardless of gender and race, but it is gender and race privilege that are at stake in the narratives we tell about monogamy and its failures', Mimi Schippers reminds us (2016, p. 4). Many feel that legal recognition may provide vital support and protection for poly families and relationships which will contribute to the realisation of the substantial value of relational autonomy (Fischel, 2016). Understanding the racialised history of the institution of marriage could lead us to consider carefully whether relationship rights are really best fought for under the banner of marriage (see Farrow, 2009).

Polikoff (2009) argues that the proper task of family law consists in protecting the diversity of family and care relationships, rather than specific cultural symbols, practices or configurations. Such an approach would discard with the belief that any singular institution 
could safeguard recognition and protection in an inclusive fashion. One of the slippery slope scenarios evoked by Kurtz (2003) warns that same-sex marriage would lead to the end of marriage, dissolving it 'into a variety of relationship contracts, linking two, three, or more individuals (however weakly and temporarily) in every conceivable combination of male and female'. I sympathise with Lisa Duggan (2004), who argues that rather than simply refusing the empirical hypothesis of this projection, we should embrace it and use it as a road-map. If official family policy would aim at truly supporting a diversity of legal statuses with the capacity for catering for people's diverse needs and if it opened up all those statuses to everybody, then - and only then - might ' $[\mathrm{t}] \mathrm{he}$ moral conservative's nightmare vision of a flexible menu of options (...) become a route to progressive equality!' (Duggan, 2004). There is an alternative to simply opposing the slippery slope logic: That is embracing it with a subversive intention!

\section{Cited Court Cases}

Bowers v. Hardwick 478 U.S. 186 (1986)

Civil Rights Act, 14 Stat. 27-30 (1866)

Defense of Marriage Act (DOMA), Pub.L. 104-199, 110 Stat. 2419 (1996)

Lawrence v. Texas, 539 U.S. 558 (2003)

Loving v. Virginia, 388 U.S. 1 (1967)

Obergefell v. Hodges 576 U.S. (2015)

United States v. Windsor, 570 U.S. (2013)

Reynolds v. United States, 98 U.S. (8 Otto.) 145 (1878) 


\section{References}

Ahmed, S. (2004) The cultural politics of emotion. Edinburgh: Edinburgh University Press.

Ahmed, S. (2011). Problematic proximities: Or why critiques of gay imperialism matter. Feminist Legal Studies, 19(2), 119-132.

Antalffy, N. (2011). Polyamory and the media. SCAN - Journal of Media, Arts and Culture, Vol. 8. Retrieved from: http://scan.net.au/scan/journal/display.php?journal_id=157 [Accessed: 30 January 2015].

Ashbee, E. (2007). Polyamory, social conservatism and the same-sex marriage debate in the US. Politics, 27(2), 101-107. DOI: 10.1111/j.1467-9256.2007.00285.

Ashley, S.M. (2014). Sincere but naive: Methodological queries concerning the British Columbia Polygamy Reference Trial. CRS/RCS, 51(4), 325-342.

Auchmuty, R. (2004). Same-sex marriage revived: Feminist critique and legal strategy, Feminism \& Psychology, 14(1), 101-126. DOI: 10.1177/0959-353504040307.

Aviram, H. (2010). "Geeks, goddesses, and green eggs": Political mobilization and the cultural locus of the polyamorous community in the San Francisco Bay Area. In: M. Barker \& D. Langdridge (Eds.) Understanding non-monogamies (pp. 87-93). London, UK: Routledge.

Aviram, H., \& Leachman, G. (2015). The Future of polyamorous marriage: Lessons from the marriage equality struggle. Harvard Journal of Law and Gender, 38, 269-336.

Barker, N. (2012). Not the marrying kind. A feminist critique of same-sex marriage. New York: Palgrave. 
Battalora, J. (2009) Supremacy by the law: The one man one woman marriage requirement and antimiscegenation law. In P. Galupo (Ed.) Bisexuality and same-sex marriage (pp. 7-31). New York: Routledge.

Brake, E. (2013). Recognizing care: The case for friendship and polyamory. Syracuse Law \& Civic Engagement Forum 1. Retrieved from: http://slace.syr.edu/issue-1-2013-14-onequality/recognizing-care-the-case-for-friendship-and-polyamory/ [Accessed: 16 June 2016].

Burgett, B. (2005). On the Mormon Question: Race, Sex, and Polygamy in the 1850s and the 1990s. American Quarterly, 51(1), 75-102. DOI: 10.1353/aq.2005.0002.

Cardoso, D. (2014) My Spivak is bigger than yours: (Mis-)representations of polyamory in the Portuguese LGBT movement and mononormative rhetorics. LES Online 6(1). Retrieved from: http://lespt.org/lesonline/index.php?journal=lo\&page=article\&op=viewArticle\&path \%5B\%5D=82 [Accessed: 23 February 2017].

Chatlani, H. (2006). In defense of marriage: Why same-sex marriage will not lead us ... toward the legalization of polygamy. Appalachian Journal of Law 6, 101-133.

Conrad, R., \& Nair, Y. eds. (2009) Against equality. Queer critiques of gay marriage. Lewison, ME: Against Equality Publishing Collective.

Collins, P.H. (2004). Black sexual politics. African Americans, gender, and the new racism. New York: Routledge.

Cott, N.F. (2000) Public vows. A history of marriage and the nation. Cambridge: Harvard University Press.

Davis, A. (1982). Women, race and class. London: Women's Press. 
Davis, A.D. (2010). Regulating polygamy: Intimacy, default rules and bargaining for equality. Columbia Law Review, 110(8), 1955-2046.

deBoer, F. (2015, June 26). It's time to legalize polygamy. Why group marriage is the next horizon of social liberalism. Politico Magazine. Retrieved from: http://www.politico.com/magazine/story/2015/06/gay-marriage-decisionpolygamy-119469 [Accessed: 12 June 2016].

Denike, M. (2010). What's queer about polygamy? In: R. Leckey \& K. Brooks (Eds.) Queer theory, law, culture, empire (pp. 137-154). London: Routledge.

Denniston, L. (2015). Opinion analysis: Marriage now open to same-sex couples. SCOTUSBlog, 26 June 2016. Retrieved from: http://www.scotusblog.com/2015/06/opinion-analysis-marriage-now-open-tosame-sex-couples/ [Accessed: 18 June 2016].

Duggan, L. (2004, March 15). Holy matrimony. The Nation. Retrieved from: https://www.thenation.com/article/holy-matrimony/ [Accessed: 08 May 2017].

Eisner, S. (2012). Bi notes for a bisexual revolution. San Francisco, CA: Seale Press.

Emens, E.F. (2004). Monogamy's law: Compulsory monogamy and polyamorous existence. New York University Review of Law \& Social Change, 29, 277-376.

Ertman, M.M. (2010). Race treason: The untold story of America's ban on polygamy, Columbia Journal of Gender and Law, 19, 287-366.

Farrow, K. (2009). Is gay marriage anti black? In R. Conrad \& Y. Nair (Eds.) Against equality. Queer critiques of gay marriage (pp. 21-32). Lewison, ME: Against Equality Publishing Collective. 
Fischel, J.J. (2016). A more promiscuous politics. LGBT rights without the LGBT rights. In: C.A Ball (Ed.) After marriage equality: The future of LGBT rights (pp. 181-211). New York: New York University Press.

Galupo, P. (2009) (Ed.) Bisexuality and same-sex marriage. New York: Routledge.

George, R.P. (2015, August 25). Is polyamory next? The American Interest. Retrieved from: http://www.the-american-interest.com/2015/08/25/is-polyamory-next/ [Accessed: 18 June 2016].

Gher, J.M. (2008). Polygamy and same-sex marriage - Allies or adversaries within the samesex marriage movement. William \& Mary Journal of Women and the Law, 14(3), 559603.

Hackl, A., Boyer, C.R., \& Galupo, M.P. (2013). From 'gay marriage controversy' (2004) to 'endorsement of same-sex marriage' (2012): Framing bisexuality in the same-sex marriage discourse. Sexuality \& Culture, 17(3), 512-524. DOI:10.1007/s12119-0129159-9.

Jefferson, A. (2014). Slippery slope arguments. Philosophical Compass, 9/10, 672-680. DOI: 10.1111/phc3.12161.

Klein, D.J. (2010). Plural marriage and Community Property Law. Golden Gate University Law Review, 41(1), 33-89.

Klesse, C. (2007). The spectre of promiscuity. Gay male and bisexual non-monogamies and polyamories. Aldershot: Ashgate.

Klesse, C. (2014) Polyamory - intimate practice, identity or sexual orientation?' Sexualities, 17(1/2): 81-99. DOI: https://doi.org/10.1177/1363460713511096. 
Klesse, C. (2016). Marriage, Law and Polyamory. Rebutting Mononormativity with Sexual Orientation Discourse? Ońati Socio-Legal Series Oñati Socio-Legal Series, 6(6): 13481376. Retrieved from: URL:

http://opo.iisj.net/index.php/osls/article/viewFile/734/960. [Accessed 08 June 2017].

Kurtz, S. (2003, August 4-11). Beyond gay marriage. The Weekly Standard. Retrieved from: http://www.weeklystandard.com/beyond-gay-marriage/article/4186 [Accessed: 08 January 2016].

Kurtz, S. (2005a, August 28). Here come the brides: Plural marriage is waiting in the wings. The Weekly Standard. Retrieved from: http://www.weeklystandard.com/here-comethe-brides/article/7683 [Accessed: 08 January 2016].

Kurtz, S. (2005b, March 23). Rick Santorum was Right: Meet the Future of Marriage in America. The National Review. Retrieved from:

http://www.nationalreview.com/article/213974/rick-santorum-was-right-stanleykurtz [Accessed: 23 February 2017].

Loughlin, S. (2003). Santorum under fire for comments on homosexuality [online], CNN International. Retrieved from: http://edition.cnn.com/2003/ALLPOLITICS/04/22/santorum.gays/ [Accessed: 8 January 2016].

Lenon, S., (2016). Intervening in the context of white settler colonialism: West Coast LEAF, gender equality and the Polygamy Reference. Oñati Socio-Legal Series, 6(6): 13241347. Retrived from: http://opo.iisj.net/index.php/osls/article/viewFile/738/959 [Accessed: 24 February 2017]. 
Loving More (2012). What do polys want? Retrieved from:

http://www.lovemore.com/polyamory-articles/2012-lovingmore-polyamory-survey/ [Accessed: 08 January 2016].

Manson, P. (2005). FLDS added to list of hate groups. Salt Lake Tribune . 21 April 2005.

Retrieved from: http://archive.sltrib.com/story.php?ref=/utah/ci_2677519

[Accessed: 29 April 2017].

McClintock, A. (1995). Imperial leather: Race, gender and sexuality in the colonial contest. New York: Routledge.

Mercer, K., \& Isaac, J. (1988). Race, sexual politics and black masculinity. A dosssier. In J. Rutherford \& R. Chapman (Eds.), Unwrapping masculinity (pp. 97-130). London: Lawrence and Wishart.

Mint, P. (2004). The power dynamics of cheating: Effects on polyamory and bisexuality. In: S. Anderlini-D’Onofrio (Ed.) Plural loves: Designs for bi and poly living (pp. 55-76). London: Harrington Park Press.

Myers, G. (2009). Drawing the line: Slippery slopes, sex panics, and polyamorous marriages, ExpressO. Retrieved from: http://works.bepress.com/gretchen_myers/1 [Accessed: 08 January 2016].

Pallotta-Chiarolli, M. (2010). Border sexualities, border families in schools. Lanham: Rowman and Littlefield Cherrie.

Polikoff, N.D. (2009). Law that values all families: Beyond (straight and gay) marriage, Journal of the American Academy of Matrimonial Lawyers, 22(2) 85- 104.

Puar, J. (2007) Terrorist assemblages. Homonationalism in queer times. Durham: Duke University Press. 
Rambukkana, N. (2015). Fraught intimacies. Non/monogamy in the public sphere.

Vancouver, Toronto: UBC Press.

Redding, J.A. (2010). Queer-religious potentials in US same-sex marriage debates. In R.

Leckey \& K. Brooks (Eds.) Queer theory, law, culture, empire (pp. 122-136). London: Routledge.

Rust, P.C. (1996). Monogamy and polyamory: Relationship issues for bisexuals. In B.A. Firestein (Ed.) Bisexuality. The psychology and politics of an invisible minority (pp. 127-148). London: Sage.

Sheff, E. (2011). Polyamorous families, same-sex marriage, and the slippery slope. Journal of Contemporary Ethnography, 40(5), 487-520.

Stacey, J., \& Meadow, T. (2009). New slants on the slippery slope: the politics of polygamy and gay family rights in South Africa and the United States. Politics \& Society, 37(2), 167-202. DOI: 10.1177/0032329209333924.

Schippers, M. (2016) Beyond monogamy. Polyamory and the futures of polyqueer sexualities. New York: New York University Press.

Strassberg, M. I. (1997). Distinctions of form and substance: Monogamy, polygamy and same-sex Marriage. North Carolina Law Review 75, 1501-1624.

The English Oxford Living Dictionaries (2017) Slippery Slope. Retrieved from : https://en.oxforddictionaries.com/definition/us/slippery_slope [Last Day Accessed: 22 June 2017].

Tweedy, A.E. (2011). Polyamory as a sexual orientation, University of Cincinnati Law Review, 79(4), 1461-1515. 
USA Today (2003) Washington/Politics (Excerpts from Santorum Interview. Retrieved from: https://usatoday30.usatoday.com/news/washington/2003-04-23-santorum-excerpt_x.htm (Last Day Accessed: 26 June 2017)

Volokh, E. (2003) Mechanisms of the slippery slope. Harvard Law Review, 116, 1028-1137.

Warner, M. (1999). The trouble with normal. Sex, politics and the ethics of queer life. New York: The Free Press.

Whitehead, J.C. (2012). The nuptial deal. Same-sex marriage \& neo-liberal governance.

Chicago: University of Chicago Press.

West, C. (1996). Lesbian polyfidelity. San Francisco, CA: Bokklegger Publishing.

Wilkinson, E. (2010). What's queer about non-monogamy now?. In M. Barker \& D.

Langdridge (Eds.) Understanding non-monogamies (pp. 243-254). London:

Routledge.

Willey, A. (2006). 'Christian nations', 'polygamic races' and women's rights: Towards a genealogy of non/monogamy and whiteness. Sexualities, 9(5), 530-546. DOI: $10.1177 / 1363460706069964$.

Yoshino, K., 2000. The epistemic contract of bisexual erasure. Stanford Law Review, 52(2), $353-461$.

\footnotetext{
${ }^{1}$ LGBTQ is an umbrella term that stands for lesbian, gay, bisexual, transgender and queer. I use it occasionally for the sake of brevity to refer to a cluster of identities, intimacies and diverse forms of political activism. I also use the term LGBT (lesbian, gay, bisexual, transgender) when I talk about more formalised forms of lobby politics that have been salient in the US American campaign for same-sex marriage (Whitehead, 2012). It does not make sense to include a reference to queer here, because queer activism has been mostly opposed to both same-sex marriage and representative identity and/or lobbying politics (Conrad \& Nair, 2009).

${ }^{2}$ In Bowers v. Hardwick (1986), the United States Supreme Court upheld the constitutionality of a Georgia sodomy law that criminalised oral and anal sex between consenting adults on moral grounds.
} 


\begin{abstract}
${ }^{3}$ I have used the term same-sex marriage throughout this article. The formulation 'gay marriage' is problematic for a variety of reasons. Firstly, the term ascribes a specific sexual orientation to those who may decide to enter a marriage with a person of the same gender (i.e. gay or lesbian). It therefore renders invisible bisexual, pansexual or queer-identified people in same-sex marriages. Using the generic term 'gay marriage' further enters an androcentric bias, since in its contemporary usage 'gay' is mostly used to refer to gay men (rather than lesbians). Organising the debate on same-sex marriage under the heading 'gay marriage' is thus exclusive with regard to several registers (see Hackl et al. 2013).
\end{abstract}

